\title{
An Analysis of Public Order Policing in the Gauteng Province, South Africa
}

\author{
Zephania Mqedi Mkhwanazi ${ }^{1}$ and Dee Khosa ${ }^{2, *}$
}

${ }^{1}$ South African Police Services, Public Order Policing, Operational Response Services, Koedoe Building, 236 Pretorius St, Pretoria Central, Pretoria, 0001, South Africa

${ }^{2}$ Tshwane University of Technology, Aubrey Matlala Street, Soshanguve, Pretoria, South Africa

\begin{abstract}
Background: Public order policing (POP) has attracted considerable interest from the academic community due to public protests in South Africa. This is not surprising given that it represents an important component of police work. As South Africa's democracy has been maturing, the democratic dispensation brought the promise of civil liberties and a human rights culture. Although these parallel developments brought prospects of accountability and legitimacy by the South African Police Service (SAPS), the restoration of public order, especially during public protests, has remained a challenge for the SAPS.

Purpose: The objectives of this research were threefold: to explore the role of the POP unit; to explore its capacity to respond to public protests; and to determine the effectiveness of the integrated interventions of the relevant stakeholders to restore engagement and order.

Methods: A qualitative research approach employing semi-structured interviews was utilised. To understand the policing of public protests, purposeful sampling was utilised to select 25 participants comprising community members, municipal officials, and POP members. These participants were selected since they are directly involved either in responding to public order or being part of protests, and it was therefore envisaged that their contribution would assist in understanding how protests are responded to.

Conclusion: The findings indicate that when the POP units that are mandated to fulfil these goals are not effective, disruptions of public order are minimised and the destructive consequences of those that do occur are contained. The results illustrate that the restoration of public order necessitates regenerating public order characterised by low expectations of violence and a heightened respect for human rights.

Recommendations: This article recommends that the relevant stakeholders in collaboration with the POP unit must respond adequately to the maintenance of safety and security during protests. The relevant stakeholders and the POP unit should enhance the effectiveness of the current strategies to be able to deal with anticipated public violence and disorder, improvement of the intelligence-gathering process to plan properly, adequate and proper training facilities, reviewing and updating of training manuals, and methods based on lessons learned and best practices to ensure that the training is relevant. POP members must undergo regular training and in-service training to maintain their fitness levels, standards, proficiency, and competencies.
\end{abstract}

Keywords: Protests, crowd management, restoration of public order, riots, public order policing, violence.

\section{INTRODUCTION}

South Africa is confronted with violent strikes, mass actions, and protests, as well as an increase in violent crime rates. The number of protests in the country has been increasing, and there is an urgent need for policing to avoid the risk of violence, loss of life, and criminal behaviour. In South Africa, protests occur quite often; perhaps indicating that citizens make frequent demands of the government. Protesting is a way for protesters to register their complaints about matters that are of serious concern to them. Whenever the members of the Public Order Policing (POP) Unit are involved in crowd management and control, whether violent or not, there are always questions about the appropriateness of the police response. The protesters' objective is to highlight their plight to address recurrent

*Address correspondence to this author at the Tshwane University of Technology, Aubrey Matlala Street, Soshanguve, Pretoria, South Africa; Tel: +2712 382 9811; E-mail: khosad@tut.ac.za problems that have constantly been raised by the affected people or communities (Alexander, Runciman and Maruping, 2015). Albrecht, Dow, Plecas and Das (2015) state that in this state of marginalisation, exclusion, and desperation, rumours of mismanagement, corruption, or nepotism fuel violent protests. The disruptive or violent nature of the protests tends to attract huge media coverage, which one could argue advances such publicity stunts. This sentiment is supported by Pillay (2016), who states that people know the impact of violence in attracting attention and achieving objectives. Samad (2009) expands on this by stating that protests must receive media coverage to be effective, which is why even non-violent organisations depend on conflict and create crises in order to receive public attention. The South African Police Service (SAPS) has a duty to enforce compliance. The objective of the SAPS is to guarantee the safety and security of the protesters and the public (nonprotesters), as well as safeguarding property against 
destruction. The police may use force for crowd control where there are apparent intentions to kill or to seriously injure persons or to seriously damage or destroy property. However, such use of force must be moderate and proportionate to the circumstances.

Public protests are rarely peaceful and often result in violence. Potential factors that contribute to protest violence include (1) failing infrastructure and services; (2) high expectations of a response; (3) high youth unemployment; (4) a large enough group; (5) a low level of access to resources; (6) inequality, injustice, and perceived marginalisation; (7) highly motivated individuals; (8) trust/distrust in authorities; (9) a resonance in the larger population about the cause of action; (10) the attitude of leaders towards violence (latent or patent tolerance of violence); (11) responsiveness to grievances; (12) media interest in the issue; (13) the nature of the police response; and (14) official responses after violence has erupted.

The restoration of public order means many things to many people (Alexander, Runciman and Maruping, 2015; Bruce, 2016, Buch, 2012, Marks and Bruce, 2014; Mofokeng, 2018). The central obligation of the government is to uphold public order (Buch, 2012). Bruce (2016) points out that numerous societies are of the view that the concept "public order policing" ("POP") relates to the policing of demonstrators - who might be aggrieved due to some reason, such as a lack of basic services - who are wrongly classified as dissenters in South Africa.

According to Alexander et al. (2016), a further persistent source of misunderstanding is the predisposition of both the public and those in the higher echelons in law enforcement, who mistakenly or wrongfully deduce that numbers reflecting "unrest" crowd occurrences are statistics for violent protests. Buch (2012) and Masiloane and Pillay (2017) are of the view that public order should be viewed with a lens that determines whether the police are capable of maintaining law and order within the ambit of the prevailing prescripts, or whether there is a need to establish the effectiveness of these prescripts to enable the police to maintain public order during protests. Research conducted in 2011 indicated that the level of training of SAPS members in crowd management and control (POP) lacked content. Mthethwa (2011) states that the basic and refresher training for police officers and others involved in law enforcement should include courses not only in human and constitutional rights, but also scientific techniques and other best practices for the professional discharge of their functions in a protest environment.

Spontaneous public protests do not provide the luxury of planning but call for immediate reaction. Such situations call for sound judgement and the correct assessment of the situation. In order to ensure the correct responses, it is required that each province must facilitate the development of contingency plans up to police station level or at least cluster level to provide minimum guidance to respond to public protest types (Mthethwa, 2011). An example is the Farlam Commission, which is the latest commission to have been appointed by the president to examine police actions, after the killing of 34 mineworkers at the Marikana mine in August 2012. The commission, supported by experts, was unanimous in its view that automatic rifles and the like have no place in POP and that military assault weapons have no place in law enforcement. The immediate withdrawal of R5 rifles was recommended and any replacement weapon system should not be capable of "automatic fire" mode (Marikana Commission of Inquiry, 2015).

The objectives of this paper were to analyse the role of the POP unit; to analyse its capacity to respond to public protests; and to determine the effectiveness of the integrated interventions of the relevant stakeholders to restore public order to bring legitimacy to the SAPS.

\section{DISCUSSION}

\subsection{Crowd Psychology Theory and Crowd Management}

Theories of policing include linking the basic purposes and historical developments of policing to hegemonic notions of social control and social order and ideologies of justice in a society (Herbert, 2006). One key question that society will always ask is whether the police are providing a service that seeks to benefit all members of society or whether they serve as a repressive force that protects the interests of the few at the expense of the many. The crowd psychology theory is therefore crucial as it provides insight into various factors that relate to policing and police behaviour.

Research indicates that early "classic" theories viewed crowds as being inherently dangerous and prone to disorder. On the one hand, it was assumed that individuals lost their identity in the "anonymity of the crowd" and become subject to the "laws of 
imitation" (Waddington and King, 2005). Random or "mindless" acts of violence and disorder were therefore understood to spread within a crowd like a disease; a "contagion" whereby "ordinary people" were likely to mimic the behaviour of others as they followed the "herd" (Hoggett and Stott, 2010). On the other hand, it was argued that criminality in a crowd is the result of the convergence of "riff-raff" - those predisposed toward criminality (Waddington, 1987, 1991, 1993, 1994; Jefferson, 1990; Della Porta and Reither, 1998; Sheptycki, 2002).

As a result, this traditional understanding of crowds - most commonly associated with the work of Gustave Le Bon - led to police perspectives and training that focused on "controlling" crowds through the use of force (Drury and Winter, 2003). Correspondingly, there was a relative absence of strategies that focused on the facilitation of crowds and the use of communication and dialogue (Her Majesty's Inspectorate of Constabulary, 2009). Despite their common-sense appeal, these classic theories have not withstood academic scrutiny. This is primarily because they lacked explanatory power and failed to account for the observed patterns of and limits to collective action. The classic theories were inadequate because they could not predict or explain when riots were likely to happen, who would and would not become involved, or what would or would not subsequently become a target of collective attack. A new model of understanding crowd dynamics developed from research on the 1980 riot in the St Paul's area of Bristol (Reicher, 1996). Social psychological research suggests that where the police hold a theoretical view of the crowd in line with the "classic" crowd psychology of Gustave Le Bon, it can lead to police practices that inadvertently escalate in public disorder (Reicher, 1996).

Over the past 30 years, social science has been amassing a large body of scientific evidence and theories that suggest that there is a very intimate relationship between the dynamics of crowd violence and POP (Waddington and King, 2005; Waddington, 1987, 1991, 1993, 1994, 2007; Jefferson, 1990; Della Porta and Reiter, 1998; Sheptycki, 2002; King and Waddington, 2004). Much of this literature points to a progressive global transition, post-World War II, from "reactive" policing grounded in the threat and use of force to a more "proactive" consent-based approach that relies less on the use of force and more on communication and negotiation (McCarthy and McPhail, 1998). This distinction is often contrasted in terms of a strategic orientation to "escalated force" versus "negotiated management" (Waddington, 2007).
Yet there is a strong debate in the same literature about how to best deliver the strategy of "negotiated management" tactically. Waddington (1987; 1991; 1993; 1994) has consistently argued that it is best realised through paramilitarisation. In contrast, Jefferson (1990) has argued that paramilitarisation carries with it an inherent tendency towards escalated force via "a massive and highly oppressive police presence". However, what both perspectives share is the assumption that police tactics can and do have the capacity to negatively impact on crowd dynamics. Moreover, despite evidence of these general trends in $\mathrm{POP}$, other researchers have highlighted how these different strategic and tactical approaches can actually be applied simultaneously by different forces in the same country and even in the same event (Della Porta and Reiter, 1998; Sheptycki, 2002; De Lint, 2005). Given that this variability is acknowledged, the research literature on POP raises two fundamental questions: what governs the application of different styles of POP, and what are the underlying social psychological processes that determine their impacts on crowd dynamics?

The primary theoretical model that seeks to address the former question is that developed by Della Porta and Reiter (1998), who propose a multiplicity of interrelated factors, such as the surrounding legal framework, the culture of the police, the political context, and the pattern of interaction between the police and the crowd. Della Porta and Reiter (1998) further argue that these variables function together to produce "police knowledge", which in turn determines the style of policing that is adopted. Consequently, the literature acknowledges that police psychology plays an important role in subsequent crowd dynamics (Della Porta and Reiter, 1998; Sheptycki, 2002; De Lint, 2005). However, there is as yet no clear analysis of the specific role that the police's theoretical understanding of crowd psychology plays in this "police knowledge", nor on how this aspect of knowledge influences police strategic and tactical decisions during an event. This research and theory on the former question mesh well with a now substantial body of literature in social psychology that begins to address the latter.

\subsection{The Role of the Public Order Policing (POP) Unit as an Effective Public Order System}

Again, Section 205(3) of the Constitution (Republic of South Africa [RSA], 1996) and section 13 of the SAPS Act (RSA, 1995) mandate the National Commissioner of the SAPS to establish and maintain 
national POP capacity. Both the Constitution and section 13 of the SAPS Act mandate the SAPS to contain violence and maintain safety and security for all who reside within the Republic. Various legislative and regulatory frameworks, such as the Constitution and the SAPS Act Standing Order of 2013 (SAPS, 2013), which regulate crowd management incidents, and the Criminal Procedure Act (RSA, 1977), afford the SAPS with provisions in one way or another regarding the use of force.

The recent violent protests in Vuwani that erupted after the community lost the court case on their incorporation into the Collins Chabane Municipality is a classic example (Masiloane and Pillay, 2017). "On the other hand, the cause of violence could be a deliberate act by the protesters to attract public attention by any means. The disruptive or violent nature of the protests tends to attract huge media coverage, which one could argue advances such publicity stunts" (Masiloane and Pillay, 2017). Mofokeng (2018) states that "the prevention of violence during civil protests and avoidance of the need to resort to force by the SAPS should be guiding principles in the management of any public order situation in South Africa". Needless to say, during protests, the major objective of any police agency is to contain violence and maintain safety and security. Protests reveal the capability of the police to maintain and restore order using the minimum amount of force that is required to achieve their ultimate goal. This has a direct bearing on police effectiveness and efficiency in a democratic state (Mofokeng, 2018; Masiloane and Pillay, 2017).

In terms of the National Peace Accord of 1991 (United Nations, 1991), read together with the Constitution and the SAPS Act (RSA, 1995), SAPS officers are expected to perform at a higher standard of conduct in the execution of their duties than expected from others and in pursuance thereof must monitor different types of protests such as service delivery protests, gatherings, marches, and demonstrations, as well as erect police barricades. During the policing of crowds, the POP unit in particular is required to emphasise through the execution of its mandate that there is no place within its ranks for practices based on personal or racial prejudice, excessive force, or any unlawful actions. In view of the changing landscape in South Africa, the democratic dispensation demands that POP units are required to exercise restraint in the pursuance of public order and restoration, and are expected to use minimum force that is appropriate under the circumstances (Mofokeng, 2018; Montesh, 2012).
Bernard, Paoline and Pare (2005) point out that the general systems theory has been nested in a long tradition in the natural, behavioural, and social sciences. There have, however, been conflicting views among scholars within both the natural and social sciences about whether the criminal justice system should be considered a "system". Bernard et al. (2005) are of the view that the criminal justice system "was not a 'system' at all; observing the nonexistence of amalgamation amongst entities and the withininstitution dissimilarities that occurred through diverse settings". Several authors within the social sciences (Conklin, 1992; Hart, 1996; Roelofse, 2012; Shane, 2010) concentrating on the three constituent components of policing - namely society, the police organisation, and the individual officers - maintain that these three constituent components of policing encompass a system. For the purposes of this article, POP units should be considered as public order systems that should be adhered to in order to obtain legitimacy among the public in South Africa.

Bruce (2016) postulates that "the SAPS are authorised with preventing or managing disorder". The South African Civilian Secretariat for Police (2016) elaborates that

the ability to deliver on this directive is reliant on the POP units being adequately structured, trained and capacitated to be able to restore public order within the constitutional perimeters of acknowledging the rights to dignity, bodily integrity and peaceful protest, and the need to remain citizen-centred for the SAPS to adequately manage crowds and public violence. The police also require support from and joint interventions with the government departments that are the source of the community frustration that led to the protest.

The protection of people who exercise their constitutional right to demonstrate peacefully against violence in general and police violence in particular is reaffirmed by the South African Human Rights Commission (cited in Masiloane and Pillay, 2017), which investigated the killing of Andries Tatane by the police in the Free State province in 2011. This emphasises the need for police actions to be consonant with and uphold the rights of people to protest peacefully and unarmed (Masiloane and Pillay, 2017). 


\subsection{Successful Crowd Management According to Best Practices}

Lord John Steven's Independent Police Commission published a report on the future of policing in 2013 (Stott and Geoff, 2013). As part of the consultative process for this report, a paper on the status of evidence and its implications for the future of POP was published (Stott and Geoff, 2013).

A successful POP operation evaluated against the laws and guidance set out above can be assessed along the following four dimensions:

1. Facilitating the legitimate rights and expectations of crowd members along with those affected by the crowd event (e.g., police, other communities);

2. Reducing the risk of disorder and other forms of criminality in the context of a crowd event;

3. Deployment of no more police resources than are necessary to achieve (1) and (2); and

4. An outcome that has long-term benefits such as improving police-community relations and ensuring that the management of future related crowd events is easier (i.e., has a de-escalation impact).

\section{MATERIALS AND METHODS}

A qualitative research approach employing semistructured interviews was utilised for this research. Purposeful sampling was utilised to select 25 participants comprising community members, municipal officials, and POP members. These participants were chosen because of their direct involvement in either responding to public order or being part of protests; it was therefore envisaged that their contribution would assist in understanding how protests are responded to by police in Gauteng. This paper was a qualitative exploratory investigation seeking to gather information about participants' representation of restoration of order in an effort to challenge what is exaggerated about protest policing among dominant groups. Once the proposed research obtained ethical approval, as well as permission from the SAPS, the municipality, and community members to access participants, participants were approached to participate in this study.

The participants were included on a voluntary basis. The participants' representations of the restoration of public order were analysed by taking power relations into account. This means that a method of analysis that allows for identifying themes, particularly relating to power dynamics, was needed to uncover in which context participants placed their representations. Thematic analysis is a data-analysis method that allows for the identification of themes in raw data, such as those obtained from interviews or representations (Clarke and Braun, 2013). The social conflict theory was employed as it offers a valuable theory of meaning to contextualise the praxis of thematic analysis when investigating themes produced in social conflict contexts (Clarke and Braun, 2013). Thematic analysis aims to recognise patterns of meaning across a dataset, which affords a response to the stated research question (Clarke and Braun, 2013). Thematic analysts are interested in what these patterns are. For instance, this research was interested in which themes emerged from the data and which themes did not (Clarke and Braun, 2013). The emphasis was on the role of themes in the production of representations. Such themes may be utilised to generate undervalued representations of policing. Three themes emerged from the findings, namely improved role clarity by the POP unit; lack of adequate capacity, intelligence, and planning by the POP unit; and restoration of public order by relevant stakeholders. These themes are discussed in the following section.

\section{RESULTS}

\subsection{Theme 1: Improved Role Clarity by the POP Unit}

When asked what the role of the POP unit in restoring public order is, it emerged that the majority of the participants concurred that, despite the disagreements that unavoidably gravitate towards policing civil protests, the POP unit enjoyed a high level of public regard and trust. The findings also indicated that there were procedures to safeguard certain areas and to confine the crowds to minimise damage to property or threats to persons who collaborate with police members.

It emerged from the responses that the POP unit employed paramount promising strategies and innovative measures in order to eliminate any form of possible aggravation, such as earmarking leaders of crowds who incite crowds to resort to acts of violence and, in most instances, attempting to monitor or record each protest on video. Some of the responses contradicted one another; where some participants 
were of the view that due to increased criminality within the community, such as gangsterism, the POP unit could be deployed to bring "law and order" to minimise the growing public concern about crime and gangsterism.

"The lack of capacity from the local SAPS has created confusion about the specific tasks to be undertaken by the local police and the POP unit, the coordination and division of roles and responsibilities between the police and the $P O P$, and the precise role of the different POP units" (Participant 2).

"There is overlapping of roles between the local SAPS and that of the POP unit. In these situations, POP capabilities, especially the use of lethal force, may be unsuitable to address physical violence related to problems of public order and criminality" (Participant 11).

The responses above suggest that the public was, in general, poorly informed of the POP unit's role and thought of its role only in terms of preventing and dealing with public protests and not working together with the local community. POP officials can only take into account public views if the public knows that the POP unit exists and what its mandate is. POP officials also need to be observant of the human rights culture and inform the public of their right to protest responsibly. This will ensure that the POP unit is not visible during public protests only, but also when calm prevails. If the public is unaware of the POP unit's role, it cannot scrutinise the POP unit. The increased public awareness of the mandate of the POP unit would also reduce the stress level among POP officials when responding to public protests.

The POP units should not be seen in the same way as the Internal Stability Units of the apartheid era. The POP units should not be viewed as militarised units deployed to use force and brutality. The findings showed that public confidence in the POP unit and levels of knowledge of policing were both promising. These findings offered a glimpse of hope that the POP unit was taking a step in the right direction, although cynicism and apathy were apparent from some participants. It is the authors' view that if community members and other role players have confidence in the functioning of the POP unit, it would go a long way in improving police legitimacy. Despite the mandate of the
POP units, consultation with the local community regarding restoration of public order is a strategic attempt to improve the legitimacy of the POP units in South Africa. Research indicates that police consultation with stakeholders such as local communities may not necessarily have the same aims (Elliot and Nicholls, 1996; Jones and Newburn, 2001).

\subsection{Theme 2: Lack of Adequate Capacity, Intelligence, and Planning by the POP Unit}

When asked about the POP unit's intelligencegathering strategies, the majority of the participants concurred that violent protests and the inability of the POP units to address the recurrent complications that have been constantly raised by the affected people or communities were challenges that need strategic interventions. It is for this reason that "better intelligence" is pinpointed as the missing link or element. It also emerged that the participants from both the POP unit and the local municipality shared the sentiment that crime intelligence can be of great assistance if the POP members were to be timeously deployed, because most of the challenges relating to public protests that took place occurred abruptly. The findings also indicated political interference by local politicians. Because politicians must be seen as responsive to real public concerns, they are tempted to interfere in the performance of the POP unit, which results in unrealistic expectations among communities. Some participants said:

"The politicians made a big impact during protests as they make promises to the community and fail to fulfil them. Politicians fight against one another, and they never reach an agreement when attempting to resolve the problems" (Participant 1).

"It was correct to deploy other members from other clusters to assist and they appreciated the fact that the army was deployed, even though it was not clear what their role was as they are not trained in crowd management and they have never worked together with the SAPS in a crowd control situation before, which was a problem when taking action" (Participant 4).

"We agree with the local police station members that politicians have a great deal of influence during protests and if they had to address the protesters, they send their junior members who are not able to take decisions. Sometime they do not show up at all" (Participant 5). 
"During the unrest, the politicians were opportunistic. They sympathised with the community or demonstrators in the hope that they would vote for them. They were not objective and fought with one another, as indicated by the local police station members" (Participant 10).

"The involvement of politicians or other state agencies in crowd management causes confusion, resulting in police officers not knowing what to do. We agreed that the problem was between the protesters and the community leaders; however, it ended up being a problem between the police and the protesters" (Participant 11).

"We felt that the police were used to fight the protesters instead of protecting them. POP members, most of the time during the operations, the Joint Operation Centre (JOC) or Venue Operation Centre (VOC) did not have a relevant senior official to make decisions if the situation got out of hand during an operation. There were signs of a lack of command and control during the public protests" (Participant 15).

Montesh and Basdeo (2012) argue that "given the relative shortage of South Africa Police (SAP) personnel, the South African National Defence Force (SANDF) can play a role in precipitating and sustaining law enforcement in civil society and they can be deployed to assist in the maintenance of law and order, especially during service delivery marches and strikes". New recruits, as well as reserve police, in order to strengthen the SAPS's response to public order, and thus new selection and recruitment systems, will only have an impact on the SAPS in the long term (Montesh, 2012). Montesh (2012) argues that in terms of training more generally, it is in relation to the measures that are focused on members already in the service where most problems exist. Apart from human rights training, none of the measures implemented would appear to have any real potential to contribute to behavioural change in relation to the problem of brutality.

It also emerged that the majority of the participants concurred that good negotiation and communication skills were of the utmost importance during public protests. The SAPS participants also highlighted that the local community must give their support to the police in order to maximise the responses by all stakeholders to avert prolonged and disruptive public protests. The POP and community representatives indicated that members from the local police station were ill-disciplined during protests as some of them never reported for duty, and those who reported for duty did not devote themselves to their tasks; for example, they leaked information to the offenders. Members from the local police station mentioned that the mayor failed to address the community when invited to do so, which contributed to distrust.

Some participants said:

"There are challenges for the POP officials to identify individuals involved in acts of criminality and violence. There is a need for the POP units in understanding social identity as the key to understanding crowds' psychology and how to deal with them" (Participant 11).

"The POP members lack adequate skills and standards in terms of managing crowd dynamics associated with public disorder, as well as anticipate possible threat to public safety" (Participant 13).

The responses above highlight the need for POP officials to be exposed to continued training regarding understanding crowd psychology in order to respond adequately to possible acts of criminality and violence. The concern from both the SAPS and POP members was that there was a general lack of understanding and public knowledge of the provisions of the legislation that regulates carrying dangerous weapons during protests, namely the Dangerous Weapons Act (RSA, 2013). The majority of the community participants responded that no one considered carrying dangerous weapons a criminal offense or that it contravened any legislation.

\subsection{Theme 3: Restoration of Public Order by Relevant Stakeholders}

When asked what measures were needed to restore public order by relevant stakeholders, it emerged that the participants, especially POP members, concurred that information gathering during operations should be a priority in order to assist with proper planning. The participants were of the view that policies and directives should be communicated and monitored at the grassroots level. The members felt strongly that the partnership between the police and the community needs to be improved as it would enhance service delivery regarding physical and human resources. 
It also emerged that the participants were of the view that improved community relations would improve integrated interventions and structures during public protests. The participants' contributions made it apparent that improved techniques and proactive deployment would reduce the unnecessary use of force. It is the view of the authors that before the commencement of public protests, as well as in the aftermath, it is essential that POP officials increase consultation with local communities in an attempt to determine the possible culprits who are suspected of inciting the crowd, and the imposition of criminal justice processes without reverting to the abuse of human rights. Depending on the nature and goals of consultation, the following steps should be incorporated by the POP unit, the local SAPS, as well as the local community, as suggested by Reisman (1995).

The SAPS (2015) assert "preventing is an anticipatory public order function which ... could be applied using [the] POP unit in the area of the study". Bernard et al. (2005) assert that "at a functional level, criminal justice agencies and organisations share a variety of similarities with each other that are all related to and derived from the flow of cases through the system". Furthermore, the general systems theory argues that "each part of the criminal justice system is best understood in the context of the whole system, particularly in the context of the pressures generated by the overall flow of case processing" (Stott and Pearson, 2007). In the context of this article, preventing

anticipates the imminent rupture of public order and seeks to intervene before the rupture eventuates, with the aim of obviating it. Once a rupture has occurred, suspending seeks to arrest injuries by focusing on the agent of the violation. It involves an immediate response to the breach of public order, terminating the breach, and containing the destructive effects of the act. While preventing and suspending are specific to particular violations of public order, deterring is more general (Reisman, 1995).

Reisman (1995) also states that

[d]eterring involves the use of various conjectural devices to craft current responses that encourage putative violators in the future to refrain from violations. Deterrence may be accomplished by credible threats of consequences for violations and/or indulgences and rewards for compliance. Correcting involves identifying and adjusting individual or group patterns of behaviour that have generated or may generate ruptures of public order. Rehabilitating focuses on the victims and may involve compensation in various forms designed to redress injuries. Social reconstructing involves identifying social situations that generate or provide fertile ground for violations of public order, and introducing resources and institutions that can obviate such situations ... These seven goals are cumulative in the sense that an efficient public order system such as the POP unit should perform all of them, though the achievement of some goals, such as prevention and deterrence, will reduce the importance of some of the others. The common denominator of all of these goals, however, should be to protect, re-establish or create a public order characterised by low expectations of violence and a heightened respect for human rights. When the institutions, such as the POP units, assigned to fulfil these goals are effective, disruptions of the public order will be minimised and the destructive consequences of those that do occur will be contained (Reisman, 1995).

It is essential that the POP commanders recognise that the fundamental expectations of the public have remained relatively constant over the years. It is important to improve service delivery based on emerging trends. According to Reisman (1995), the

design of institutions for protecting and reestablishing public order at the international and national levels often fails to take sufficient account of the theoretical and policy problems involved in these tasks. There is no general institution that can be applied as a paradigm for all circumstances. In each context, an institution appropriate to the protection and re-establishment of public order in the unique circumstances that prevail must be fashioned such that it provides the greatest return on all the relevant goals of public order. 


\subsection{Theme 4: Training and the Deployment of POP Members in Affected Areas}

When asked if adequate training was provided to the local POP members in crowd management, the majority of the participants concurred that the challenge in the policing area was that the police officers were not trained in crowd management as a first responder to crowd control situations. This gap has always demanded the availability of trained members from POP units. It also emerged from the findings that the participants highlighted that the current population of POP members was aging. The implications are that these cohorts of the aging workforce were unable to run due to age and weight constraints. Even though members are very experienced, and can stand for a lot of challenges from the crowd, fitness has been identified as a problem. The other challenge highlighted by the participants was the involvement of the inexperienced constables who did not yet have adequate knowledge on how to respond to the violent situation. It emerged that these constables still need adequate or more time to gain more experience and be able to handle any crowd management situation. Some of the participants said:

"The aging workforce represents greater levels of experience, which should be a challenge for the SAPS, unless new recruits are brought in on time to be mentored by these aging members ... Also, given that during many public protests both victimisation and offending are concentrated in the teens and early20s, there may well be risks that the aging workforce will increasingly less well understand changing social and cultural phenomena, responding adequately to challenges, which may in turn translate into less efficient and effective policing. This is, in effect, an age-related diversity problem" (Participant 7).

"The current workforce is aging. Related, particularly at constable level, it seems reasonable to expect that the physical and other demands of the job will become more problematic as the workforce ages, particularly as in the workforce one notices absenteeism from older members growing steadily. One can also notice, with time, that medical retirements have increased, especially in the most recent years and this upward trend might be expected to continue. Surely this has some implications for each member as they have to work long hours during public protests due to limited workforce" (Participant 10).

"Public order training for commanders and public order units should fully incorporate training on the use of force which reflects these over-arching principles" (Participant 11).

"Police officers responsible for the planning and control of operations where the use of force is a possibility should so far as possible plan and control them to minimise recourse to the use of force, particularly lethal or potentially lethal force" (Participant 13).

Based on the above responses, it is clear that the contribution by the participants concerning the proactive deployment of members is that working together with the community will be the solution. It also emerged from the findings that POP members were of the view that political leaders must do their part in assisting the police to manage a crowd. The POP members were of the opinion that some of the political leaders took advantage of hostile protests to gain popularity. The responses from the participants who represented the local community were that the police must at all times act as quickly as possible when a situation gets out of control. These community members were of the opinion that the local municipality made promises to the community that they were unable to keep or honour. The participants further indicated that municipal officials failed to attend community meetings upon request to do so. The responses by participants from the POP unit, in addition to what was provided, made it clear that force must not be utilised in any given situation as it contributes to injuries and loss of life.

Inexperienced members demand a lot of supervision as control and command are of paramount importance when dealing with restoration and maintenance of public order in communities (Wa Afrika and Hofstatter, 2015). However, the monitoring and management approach will need a plan:

- A definite hierarchy of command and disciplined police officials. 
- Extensive training related to the use of force during protests.

- The availability of appropriate equipment for handling unrest situations.

- Operations carried out by mobile units with a good public order background and knowledge.

- The control and command approach requires police officers who are well trained and who can handle the situation professionally.

- $\quad$ Thorough preparation for any situation is needed so that mistakes are not made.

- $\quad$ Physical and human resources are essential and must be made available.

This approach requires many POP members to be deployed, and they must be well trained to deal with worst-case scenarios. These members are not kept in the vicinity but held back and brought in when the situation warrants them to take over. This approach can have a very adverse effect due to their behaviour and attitude as they will be deployed with specialised equipment. From the findings of this study, the SAPS participants further highlighted the following challenges they are confronted with daily:

- $\quad$ SAPS members are expected to provide solutions as a form of response to public protests whereby the root cause for such protests was mainly due to service delivery; at other times the reasons for public protests were unknown and the leaders did not come forward and address them.

- $\quad$ The lack of trust by local communities regarding the effectiveness and the efficiency of the criminal justice system as the local community members felt that their cases are not handled properly.

It is the view of the researchers that adequate and proper training facilities are indispensable for POP. Maintaining acceptable standards and implementing POP techniques and strategies require POP members to regularly undergo training and in-service training. For these reasons, police agencies in developed countries such as Russia, France, and England have developed dedicated facilities for POP training. These training facilities are adequately resourced and equipped with experienced trainers and equipment (Farlam
Commission of Inquiry, 2015). These training facilities are also periodically used to assess and evaluate the operational readiness of POP units and their ability to maintain minimum standards for POP. The assessment and evaluation of POP units include physical fitness, theory, and application of techniques and tactics.

POP commanders are also regularly assessed to evaluate their decision-making capabilities, command, and control. They are given practical scenarios using simulation programs where their decision making is assessed and evaluated. Police officers who fail the assessment are reassigned to other roles. The POP training facility should be resourced with highly experienced and skilled trainers to ensure that training curriculums are regularly evaluated and reviewed. It is also crucial that sustainable methodologies and best practices according to global standards are integrated into the curriculum. Due to the evolution of dynamics in managing crowds, it is vital that the curriculum for crowd management be adapted to reflect new trends of protests. In terms of the SAPS National Instructions, POP members are obliged to undergo regular maintenance exercises to ensure their readiness for operational deployment.

There is a dire need to provide psychological and wellness support to POP personnel given the stressful and violent nature of POP in South Africa. This support should be available to all police officials in the SAPS who require it. This will enable POP members to constantly be assessed and monitored even during operations to ensure that they are mentally strong while performing their policing duties. Police officers who are severely traumatised and unable to effectively perform their policing duties should be withdrawn from an operation and provided with support.

\section{RECOMMENDATIONS}

\subsection{Creating Effective Partnerships}

At provincial level, there are structures in place such as the Provincial Police Community Board, Provincial Joints, National Joints, the South African Banking Risk Information Centre, and Community Policing Forums. These structures are normally attended by members of the community, whereby all issues that affect communities are discussed. The principles of negotiations must be employed at all times. These include patience, time, and appropriate communication aimed at facilitating lawful protest activities and obtaining voluntary compliance wherever possible. It is 
recommended that the police identify the leaders of protesters and develop a mutual understanding so that decisions made attempt to resolve problems and avoid misunderstandings.

\subsection{Improvement of the Intelligence-Gathering Process}

It is imperative that the crime intelligence community must gather information before, during, and after an event so that law enforcement can plan properly. It is recommended that within POP units, officers must be provided with proper training by the Division: Crime Intelligence on how to collect and provide information for the members to execute their tasks effectively. It is recommended that the SAPS in general should improve the quality of information on protests and be able to map trends in protests over time. In areas where armed protesters are a problem, it is recommended that information officers be deployed timeously with the necessary equipment for surveillance to gather information for proper planning. The intelligence community must be able to provide early warnings on issues that are going to take place regarding violence and to be specific on who is inciting violence.

\subsection{Provisioning of Adequate Training}

The training of POP officers had been under the spotlight in many instances and two of these instances was the Tatane incident that took place in the Free State province and the Marikana massacre in the North West province. It was evident that training in the POP environment must be strengthened, especially in their curriculum. SAPS training exposes trainees to a variety of crowd management equipment, tactics, techniques, and formations related to POP operations. Further recommendations are as follows:

(1) An integrated training approach is recommended that brings together different police units that are involved in crowd management and ensures that they are trained and empowered in different scenarios and assimilation setups. The training must bring together units such as Air Wing, tactical units, negotiators trained to mediate in protests, information officers assigned to conduct forward intelligence, video operators, water cannons, armoured vehicles, liaison officers to provide a link and promote dialogue, and support teams to provide psychosocial welfare to police officers who are traumatised by the operations.
(2) It is recommended that POP members must receive continuous development and in-service training whereby scenario-based drills to enhance operational readiness are provided. Members from visible policing and the municipality that are first responders to crowd management must receive training regularly and be equipped properly.

(3) It is recommended that training should be reviewed regularly to reflect realities in crowd dynamics. This will require curriculum changes and methodological changes to adequately prepare POP members and to field test their tactics and techniques, as well as the improvement of training facilities for POP units in terms of being equipped with standardised equipment that conforms to their training. In order to ensure the above, training facilities should appoint qualified and experienced fulltime trainers, curriculum developers, assessors, and moderators.

\section{CONCLUSION}

This article discussed public views and perceptions regarding the maintenance of public order during protests with the aim of establishing the deployment of different policing agents or role players in operation for public order with the purpose of coordinating it properly. This included whether POP members knew their roles and responsibilities in terms of the maintenance of public order during protests. It further determined the need to enhance the effectiveness of the current strategies or approach for the SAPS to be able to adequately deal with anticipated public violence and disorder. Adequate and proper training facilities are indispensable for POP. Maintaining acceptable standards and implementing $\mathrm{POP}$ techniques requires POP members to regularly undergo in-service training and development.

It is clear that the police understand the challenges involved in the effective and efficient policing of protests and have clear recommendations on how some of these challenges might be overcome. It might help if management in the police industry were to act on some of these recommendations, and were able to minimise the excessive use of force by police rather than continuing with the current practice of conducting investigations afterwards, which largely point out already-known factors. This suggests that some of the challenges are known but that little is done to address 
them. It is evident that the police will have to deal with unplanned protests from time to time, and the POP should therefore develop contingency measures for dealing with these regular occurrences.

\section{FUNDING}

No external funding was provided for this research.

\section{CONFLICT OF INTEREST}

No conflict of interest is applicable.

\section{ACKNOWLEDGEMENTS}

Prof. J.T. Mofokeng, for providing good arguments about public order policing.

South African Police Services, for providing permission to conduct the research.

\section{REFERENCES}

Albrecht, J.F., Dow, M.C., Plecas, D. and Das, D.K. 2015. Policing Major Events. Boca Raton: CRC https://doi.org/10.1201/b17692

Alexander, P., Runciman, C. and Maruping, B. 2015. South African Police Service Data on Crime Incidents: Preliminary Analysis. Johannesburg: Social Change Research Unit, University of Johannesburg. https://doi.org/10.17159/2413-3108/2016/v0n58a1513

Alexander, P., Runciman, C. and Maruping, B. 2016. "South Africa's Incident Registration Information System (IRIS): Its Use and Abuse in Protest Analysis." SA Crime Quarterly 58:9-21.

Bernard, T.J., Paoline, E.A. and Pare, P.P. 2005. "General Systems Theory and Criminal Justice." Journal of Criminal Justice 33:203-11. https://doi.org/10.1016/j.jcrimjus.2005.02.001

Bruce, D. 2016. "Public Order Transparency: Using Freedom of Information Laws to Analyse the Policing of Protest." SA Crime Quarterly 58: 2413-3108. https://doi.org/10.17159/2413-3108/2016/v0n58a1508

Buch, M.N. 2012. Maintenance of Public Order. Retrieved 12 July, 2019 (https://www.vifindia.org/print/1307?via=at).

Clarke, V. and Braun, V. 2013. "Teaching Thematic Analysis: Overcoming Challenges and Developing Strategies for Effective Learning." The Psychologist 26(2):120-23.

Conklin, J.E. 1992. Criminology. 4th ed. New York: MacMillan.

De Lint, W. 2005. "Public Order Policing: A Tough Act to Follow?" International Journal of the Sociology of Law 33(4):179-99. https://doi.org/10.1016/j.ijsl.2005.08.001

Della Porta, D. and Reiter, H. 1998. Policing Protest: The Control of Mass Demonstrations in Western Democracies. https://doi.org/10.5749/j.ctttv1tv

Drury, J. and Winter, G. 2003. "Social Identity as a Source of Strength in Mass Emergencies and Other Crowd Events." International Journal of Mental Health 32(4):77-93. https://doi.org/10.1080/00207411.2003.11449599

Elliot, R. and Nicholls, J. 1996. It's Good to Talk: Lessons in Public Consultation and Feedback. London: Police Research Group.

Farlam Commission of Inquiry. 2015. Farlam Commission of Inquiry Report. Retrieved 22 April, 2020 (http://sd-
report.lonmin.com/2015/pdf/Farlam_Commission_of_Inquiry_ Report.pdf).

Hart, J.M. 1996. "The Management of Change in Police Organizations." Pp. 199-217 in Policing in Central and Eastern Europe: Comparing First-hand Knowledge With Experience From the West (Part IV), edited by M. Pagon. Ljubljana, Slovenia: College of Police and Security Studies.

Herbert, S. 2006. "Tangled up in Blue: Conflicting Paths to Police Legitimacy." Theoretical Criminology 10(4): 481-504. https://doi.org/10.1177/1362480606068875

Her Majesty's Inspectorate of Constabulary (HMIC). 2009. Adapting to Protest: Nurturing the British Model of Policing. London: HMIC.

Hoggett, J. and Stott, C. 2010. "The Role of Crowd Theory in Determining the Use of Force in Public Order Policing." Policing and Society 20(2):223-36. https://doi.org/10.1080/10439461003668468

Jefferson, T. 1990. "The Case against Paramilitary Policing." The British Journal of Criminology 33(1):325-52.

Jones, T. and Newburn, T. 2001. Widening Access: Improving Police Relations with Hard-to-Reach Groups. London: Police Research Group.

King, M. and Waddington, D. 2004. "Flashpoints Revisited: A Critical Application to the Policing of Anti-Globalization Protest." Policing and Society, 15(3):255-82. https://doi.org/10.1080/10439460500168584

Lawes, A. 1993. Management Skills for the Information Manager Vermont: Ashgate Publishing Limited.

Marikana Commission of Inquiry. 2015. National and International Concern Arising out of the Tragic Incidents at the Lonmin Mine in Marikana in the North West Province. Retrieved 15 May, 2021 (http://www.sahrc.org.za/ home/21/files/marikanareport-1.pdf).

Marks, M. and Bruce, D. 2014. "Groundhog Day? Public Order Policing Twenty Years into Democracy." South African Journal of Criminal Justice 27(3):346-76, 362-68.

Masiloane, D. and Pillay, D. 2017. "The policing of public protests in South Africa with specific reference to the Free State province." Acta Criminologica: Southern African Journal of Criminology 30(2):128-46.

Mccarthy, J. and Mcphail, C. 1998. When Riot Cops are not Enough: The Policing and Repression of the Occupy Oakland Movement. New Jersey: Rutgers University.

Mofokeng, J.T. 2018. "A Critical Analysis of the South African Police Service's Management of Civil Protests." International Journal of Social Sciences and Humanity Studies 10(1):13349.

Montesh, M. 2012. "Police Brutality and the Policing of Public Gatherings in South Africa." All Africa Criminal Justice Society 2012:170-204. https://doi.org/10.5787/40-1-985

Montesh, M. and Basdeo, V. 2012. "The Role of the South African National Defence Force in Policing." Scientia Militaria, South African Journal of Military Studies 40(1):71-94.

Mthethwa, N. 2011. New Policy on Policing Public Order Protests Ministry. Retrieved 12 July, 2019 (http://www.politicsweb. co.za/party/new-policy-on-policing-public-order-protestsmini).

Pillay, D. 2016. "An Analysis of the Policing of Service Delivery Protests in the Free State." Master's thesis, University of South Africa, Pretoria.

Reicher, S. 1996. The Psychology of Crowd Dynamics. Retrieved 13 February, 2019 (https://pdfs.semanticscholar.org/2ed1/ dacbd7177d6c1709dda3a8254e7e58a6d1af.pdf).

Reisman, W.M. 1995. Institutions and Practices for Restoring and Maintaining Public Order. Retrieved 12 July, 2020 (https://scholarship.law.duke.edu/cgi/viewcontent.cgi?article= $1363 \&$ context=djcil) 
Republic Of South Africa (RSA). 1977. The Criminal Procedure Act, No. 51 of 1977. Pretoria: Government Printers.

Republic Of South Africa (RSA). 1995. The South African Police Services (SAPS) Act, No. 68 of 1995. Pretoria: Government Printers.

Republic Of South Africa (RSA). 1996. Constitution of the Republic of South Africa, Act 108 of 1996. Pretoria: Government Printers.

Republic Of South Africa (RSA). 2013. The Dangerous Weapons Act, No. 15 of 2013. Pretoria: Government Printers.

Roelofse, C.J. 2012. "A Critical Assessment of the Constitutional Mandate of the South African Police Service in Accordance with Criminological Perspective on Crime Prevention." Acta Criminologica 23(2):42-60.

Samad, S.A. 2009. "Non-violence in the Civil Rights Movement in the United States of America." Unpublished thesis, Free University, Berlin.

Shane, J.M. 2010. "Organisational Stressors and Police Performance." Journal of Criminal Justice 38(4):807-18. https://doi.org/10.1016/j.jcrimjus.2010.05.008

Sheptycki, J. 2002. "Accountability Across the Policing Field: Towards a General Cartography of Accountability for PostModern Policing." Policing and Society 12(4):323-38. https://doi.org/10.1080/10439460220000055

South African Civilian Secretariat for Police 2016. White Paper on Policing. Pretoria: South Africa.

South African Police Service (SAPS). 2013. SAPS Act Standing Order 2013: Media Communication in the South African Police Service. Pretoria: SAPS.

South African Police Service (SAPS). 2015. SAPS Annual Report 2014-2015. Pretoria: Government Printer.
Stott, C. and Geoff, P. 2013. Public Order Policing: Evidence Review. Retrieved 12 July, 2020 (https://www.n8research.org.uk/ media/PublicOrder_Evidence-Review.pdf).

Stott, C. and Pearson, G. 2007. Football 'Hooliganism', Policing and the War on the 'English Disease'. London: Pennant Books.

Wa Afrika, M. \& Hofstatter, S. 2015. "When Cops Stoop to Criminal Tactics." Sunday Times, November 15, p. 8.

Waddington, D.P. 2007. Policing Public Disorder: Theory and Practice. Cullompton: Willan. https://doi.org/10.1093/police/pam057

Waddington, D.P. and King, M. 2005. "The Disorderly Crowd: From Classical Psychological Reductionism to Socio-Contextual Theory - The Impact on Public Order Policing Strategies." The Howard Journal of Criminal Justice 44(5):490-503. https://doi.org/10.1111/j.1468-2311.2005.00393.x

Waddington, P.A.J. 1987. "Towards Paramilitarism? Dilemmas in Policing Civil Disorder." British Journal of Criminology 27:3746. https://doi.org/10.1093/oxfordjournals.bjc.a047650

Waddington, P.A.J. 1991. Strong Arm of the Law: Armed and Public Order Policing. Oxford: Oxford University Press.

Waddington, P.A.J. 1993. "Dying in a Ditch: The Use of Police Powers in Public Order." International Journal of the Sociology of Law 21:335-53.

Waddington, P.A.J. 1994. Liberty and Order: Public Order Policing in a Capital City. London: UCL Press.

United Nations 1991. National Peace Accord of 1991. Retrieved 12 July, 2020 (https://peacemaker.un.org/sites/peacemaker. un.org/files/ZA_910914_National\%20Peace\%20Accord.pdf).

https://doi.org/10.6000/1929-4409.2021.10.152

(C) 2021 Mkhwanazi and Khosa; Licensee Lifescience Global.

This is an open access article licensed under the terms of the Creative Commons Attribution Non-Commercial License (http://creativecommons.org/licenses/by-nc/3.0/) which permits unrestricted, non-commercial use, distribution and reproduction in any medium, provided the work is properly cited. 